\title{
Identification of Staphylococcus pettenkoferi Isolated from Blood Culture
}

\author{
Hyein Kang, Namhee Ryoo \\ Department of Laboratory Medicine, Keimyung University School of Medicine, Daegu, Korea
}

Staphylococcus pettenkoferi is a coagulase-negative staphylococci (CoNS) of growing concern. As CoNS could be an important cause of infections in hospitalized patients, especially in immunocompromised patients, accurate identification is critical to timely and effective treatment. In the past, S. pettenkoferi was not identifed by conventional methods or was misidentified as another Staphylococcus species or another genus. To the best of our knowledge, this is the first case of S. pettenkoferi identified using Vitek
MS (bioMérieux, France). Two patients admitted to our hospital were confirmed to have bacteremia caused by $S$. pettenkoferi, which was identified in blood cultures using Vitek MS (bioMérieux). Therefore, we recommend using the Vitek MS (bioMérieux) for rapid and accurate identification of the pathogen causing bloodstream infection when CoNS is suspected. (Ann Clin Microbiol 2019;22:77-79)

Key Words: Blood culture, Staphylococcus pettenkoferi

\section{INTRODUCTION}

Among coagulase-negative staphylococci (CoNS) species, Staphylococcus pettenkoferi is a relatively recently discussed member. It was first isolated from blood culture in 2002 [1]. Several additional cases have been reported including bacteremia accompanied with tuberculosis and Stevens-Johnson syndrome [2] and osteomyelitis [3]. There were 2 case reports of $S$. pettenkoferi in Korea [2,4]. This novel isolate was hardly identified by conventional automated identification methods like Vitek system, thus 16S rRNA sequencing had to be used for confirmation. The matrix-assisted laser desorption ionization time-of-flight mass spectrometry (MALDI-TOF MS) was introduced to laboratories recently and the identification of this isolate was confirmed by Brucker Biotyper (Brucker Daltonics, Bremen, Germany), but not Vitek MS (bioMérieux, Marcy-L'Etoile, France) [4]. The present report describes two cases of $S$. pettenkoferi bacteremia identified by Vitek MS (bioMérieux).

\section{CASE REPORT}

A 38-year-old woman was admitted to our hospital for chemotherapy of gastric cancer after 3 years of the surgery due to peritoneal carcinomatosis. The patient was febrile on the day of admission, but otherwise was asymptomatic. She had mild spiking fever continuously, so blood samples were drawn for culture. They were inoculated into aerobic and anaerobic blood culture bottles and incubated in a BacT/ALERT 3D blood culture instrument (bioMérieux, Marcy-L'Etoile, France). The bottles were scored positive after 22 hours and 40 minutes of incubation at $37^{\circ} \mathrm{C}$. The colony was $1.0-2.0 \mathrm{~mm}$ sized circular, glistening, and whitish with no hemolysis on blood agar plate. Microscopic examination revealed Gram-positive cocci in clusters and was negative for coagulase and positive for catalase, so the isolates were initially concluded as CoNS. With the Vitek2 system (bioMérieux, Marcy-L'Etoile, France), it was identified as Staphylococcus auricularis or Staphylococcus capitis with low discrimination of $50 \%$ each. Therefore, Vitek MS IVD Database Version 3.0 (bioMérieux) was used and identified as S. pettenkoferi $(99.9 \%)$. As the two results were different, se-

Received 21 February, 2019, Revised 27 May, 2019, Accepted 2 June, 2019

Correspondence: Namhee Ryoo, Department of Laboratory Medicine, Keimyung University School of Medicine, 1035 Dalgubeol-daero, Dalseo-gu, Daegu 42601, Korea. (Tel) 82-53-258-7939, (Fax) 82-53-258-4228, (E-mail) nhryoo@dsmc.or.kr

(c) The Korean Society of Clinical Microbiology.

(․) This is an Open Access article distributed under the terms of the Creative Commons Attribution Non-Commercial License (http://creativecommons.org/licenses/by-nc/4.0) which permits unrestricted non-commercial use, distribution, and reproduction in any medium, provided the original work is properly cited. 
Table 1. Susceptibilites for Staphylococcus pettenkoferi reported in this study

\begin{tabular}{|c|c|c|c|c|}
\hline \multirow{2}{*}{ Antimicrobial drug } & \multicolumn{2}{|c|}{ Case 1} & \multicolumn{2}{|c|}{ Case 2} \\
\hline & $\mathrm{MIC}(\mathrm{mg} / \mathrm{L})$ & Interpretation & $\mathrm{MIC}(\mathrm{mg} / \mathrm{L})$ & Interpretation \\
\hline Gentamicin & $\leq 0.5$ & $\mathrm{~S}$ & $\leq 0.5$ & $\mathrm{~S}$ \\
\hline Ciprofloxacin & $\geq 8$ & $\mathrm{R}$ & $\leq 0.5$ & $\mathrm{~S}$ \\
\hline Oxacillin & $\geq 4$ & $\mathrm{R}$ & 1 & $\mathrm{R}$ \\
\hline Erythromycin & $\geq 8$ & $\mathrm{R}$ & 0.5 & $\mathrm{~S}$ \\
\hline Clindamycin & $\geq 8$ & $\mathrm{R}$ & $\leq 0.25$ & $\mathrm{~S}$ \\
\hline Trimethoprim/Sulfamethoxazole & $\leq 10$ & $\mathrm{~S}$ & $\leq 0.25$ & $\mathrm{~S}$ \\
\hline Vancomycin & $\leq 0.5$ & $\mathrm{~S}$ & $\leq 10$ & $\mathrm{~S}$ \\
\hline
\end{tabular}

Abbreviations: MIC, minimal inhibitory concentration; S, susceptible; R, resistant.

quencing of the 16S rRNA gene using the MiSeq Microbial Identification System (Macrogen, Seoul, South Korea) was performed. Consensus sequence of $1547 \mathrm{bp}$ was obtained and reported the organism to be $S$. pettenkoferi (99\%). Antimicrobial susceptibility test was performed using Vitek2 system. The isolate was resistant to oxacillin (minimal inhibitory concentration (MIC) $4 \mathrm{mg} / \mathrm{L}$ ), but susceptible to vancomycin (MIC $0.5 \mathrm{mg} / \mathrm{L}$ ) and linezolid (MIC $2 \mathrm{mg} / \mathrm{L}$ ) (Table 1). After a week of meropenem therapy, no organisms were grown from blood and she was discharged from the hospital without any symptoms.

The second patient was a 90-year-old woman who had fever of unknown origin for a few days but refused to be treated. She visited emergency department with general weakness, drowsy mentality, and aphasia in addition to high fever for 4 days. She was diagnosed with encephalitis, possible diagnosis of infective endocarditis and bacteremia. Two blood samples from separate venipuncture sites were drawn for culture. After 24 hours of incubation, one aerobic bottle was positive and was subcultured onto blood agar plates. Biochemical tests revealed them as CoNS. With the Vitek2 system (bioMérieux), it was identified as Leuconostoc mesenteroides ssp. cremoris (93\%). Susceptibility test using Vitek2 system (bioMérieux) revealed sensitivity to vancomycin (MIC $10 \mathrm{mg} / \mathrm{L}$ ). As this result conflicted the fact that Leuconostoc spp. is intrinsically resistant to vancomycin, further identification was performed by Vitek MS and concluded as $S$. pettenkoferi (99.9\%). The fever subsided after the patient had received 8 days of naficillin and was transferred to other hospital with no further management because of the patient's refusal.

\section{DISCUSSION}

CoNS are important cause of infections in hospitalized pa- tients, especially in immunocompromised patients as opportunistic pathogens. It is also known that CoNS are associated with infections of indwelling catheters or implanted devices [3,5]. Staphylococcus epidermidis, Staphylococcus haemolyticus and Staphylococcus saprophyticus are the most common infectious species among CoNS [6]. However, other CoNS still can be the cause of human infections which may be mortal. Therefore, it is important to identify them accurately for treatment with proper antibiotics [7]. In a study of microbiological identification of six S. pettenkoferi isolates [4], all of them were detected by Brucker Biotyper MS (Brucker Daltonics) and 16S rRNA gene sequencing but Vitek MS (bioMérieux) did not identify any of them by Vitek MS IVD Database Version 2 (bioMérieux). By contrast, we had no difficulty to identify $S$. pettenkoferi with Vitek MS (bioMérieux) in both isolates. This novel isolate may not have been detected even though it existed in the past, because it has not been long since the MALDI-TOF MS was introduced to laboratories. Furthermore, S. pettenkoferi was newly added in the Vitek MS IVD Database Version 3.0 (bioMérieux) which was used in our laboratory. Thus it was identified successfully. The conventional identification may result in misidentification of S. pettenkoferi as Staphylococcus hominis, S. auricularis, S. capitis, Kocuria varians, or even Leuconostoc mesenteroides ssp. cremoris. More cautious approach for accurate identification of CoNS by molecular methods including Vitek MS (bioMérieux) is needed in case of bloodstream infection. Therefore, we recommend to use Vitek MS (bioMérieux) which is rapid and accurate for the identification of the pathogen in bloodstream infection [8] when CoNS is suspected. 


\section{REFERENCES}

1. Trülzsch K, Rinder H, Trcek J, Bader L, Wilhelm U, Heesemann J. "Staphylococcus pettenkoferi," a novel staphylococcal species isolated from clinical specimens. Diagn Microbiol Infect Dis 2002; 43:175-82.

2. Song SH, Park JS, Kwon HR, Kim SH, Kim HB, Chang HE, et al. Human bloodstream infection caused by Staphylococcus pettenkoferi. J Med Microbiol 2009;58(Pt 2):270-2.

3. Loïez C, Wallet F, Pischedda P, Renaux E, Senneville E, Mehdi $\mathrm{N}$, et al. First case of osteomyelitis caused by "Staphylococcus pettenkoferi". J Clin Microbiol 2007;45:1069-71.

4. Park S, Chung HS, Lee M. Clinical and microbiological characteristics of six Staphylococcus pettenkoferi isolates from blood samples. Ann Lab Med 2015;35:250-3.

5. Huebner J and Goldmann DA. Coagulase-negative staphylococci: role as pathogens. Annu Rev Med 1999;50:223-36.

6. Von Eiff C, Proctor RA, Peters G. Coagulase-negative staphylococci. Pathogens have major role in nosocomial infections. Postgrad Med 2001;110:63-4, 69-70, 73-6.

7. Becker K, Heilmann C, Peters G. Coagulase-negative staphylococci. Clin Microbiol Rev 2014;27:870-926.

8. Foster AG. Rapid identification of microbes in positive blood cultures by use of the vitek MS matrix-assisted laser desorption ionization-time of flight mass spectrometry system. J Clin Microbiol 2013;51:3717-9.

$=$ 국문초록 $=$

\section{혈액배양에서 분리된 Staphylococcus pettenkofer의 동정}

계명대학교 의과대학 진단검사의학교실

강혜인, 류남희

Staphylococcus pettenkoferi는 비교적 최근에 논의되고 있는 coagulase 음성 포도상구균(CoNS)이다. CoNS는 입원 환자, 특히 면역저하자의 감염에 중요한 원인균이 될 수 있으므로 적절한 치료를 위해 정확하게 동정하는 것이 중요하다. 과거 에 S. pettenkoferi는 전통적인 방법으로는 동정되지 않거나 다른 포도상구균 또는 다른 속으로 분류되었다. 저자의 확인 에 의하면 이 보고는 Vitek MS (bioMérieux, France)로 S. pettenkoferi가 동정된 최초의 예이다. 본 병원에 입원한 환자 두 명이 혈액배양에서 Vitek MS (bioMérieux)로 S. pettenkoferi 감염이 확진되었다. 따라서 저자는 균혈증에서 CoNS 감염 이 의심될 때 Vitek MS (bioMérieux)에 의한 병원균의 신속하고 정확한 동정을 추천한다. [Ann Clin Microbiol 2019;22:77-79]

교신저자 : 류남희, 42601, 대구시 달서구 달구벌대로 1035

계명대학교 의과대학 진단검사의학교실

Tel: 053-258-7939, Fax: 053-258-4228

E-mail: nhryoo@dsmc.or.kr 